\title{
A FÖLDHASZNÁlAT ÉS A KULTÚRA KAPCSOLATA, AVAGY A KULTÚRAMARKETING ÉS A KULTÚRAFOGYASZTÁS KIALAKULÁSÁNAK ÁLLOMÁSAI
}

\author{
Fehér Euridiké \\ PhD hallgatỏ (I. évf. Nappali), Szent István Egyetem Gödöllö, Gazdálkodás és Szervezéstudományok Doktori \\ Iskola, \\ Gazdaság és Társadalomtudományi Kar, Marketing Intézet
}

\section{SUMMARY}

Agriculture and farming created special traditions which have transformed into popular costums and believes during centuries and changing nations' cultural consumption remarkably. The change and spread of our culture itself and culture consumption is not only an ethnical and sociological question but also an economic one. This is the reason why $I$ think it is important to define the culture in the aspect of the economy as due to it we can form different culture consuming groups. I denominate three of the most important directions and dimensions according to the bibliography processed until now. These are the following: traditional, autonomous and heteronomous cultural dimensions. The first step of my research is to expound the possible consumers of these dimensions mentioned above, the permeability between dimensions or their exclusivity if there is any. At the end of the day I would like to show the new challenges and possible solutions of culture marketing considering the categories defined by me in the meantime.

Keywords: Culture and the Economy, Agriculture and culture, traditional-, autonomous-, heteronomous cultures, Sustainability as a Lifestyle , culture of consumption, culturmarketing

\section{BEVEZETÉS}

Közgazdasági szempontok alapján a kultúra fogalmát sok szempontból meg lehet közelíteni. Konferencia anyagomban a kultúra alapjait és a mindenki számára elérhető részét közjóként fogalmazom meg. Egy társadalom számára a kultúra saját értékeik megélésének erőforrása. A kultúra eredményezi az identitást és az önismeretet/társadalomismeretet. A kultúra fogyasztásából kizárni senkit sem lehet. Egy személy fogyasztása nem korlátozza a többiek hozzáférését. A fent leirt gondolatokból adódhat a kérdés, miszerint a kultúrára, mint a közjavak egyikére, hathatnak-e pozitív vagy negatív externáliák? Az externália jelentése ebben az esetben is egy gazdasági szereplő tevékenysége következtében felmerülö káros vagy elönyös, nem szántszándékkal okozott, hatás(ok), amely(ek) piaci ellentételezés nélkül befolyásolják egy másik gazdasági szereplő helyzetét. Ezen externáliák pozitív vagy negatív hatását az egyes kultúra fogyasztói rétegekben bekövetkezett változások alapján kívánom megvizsgálni további munkáimban (Bulla, 2011.).

A gazdaság kapcsolata a kultúrával három fő szempont szerint értelmezhető leginkább, mégpedig a gazdaság és a kultúra heterogenitása kapcsán (Karikó, 2006.): A hasznosság és az általános, örök emberi célok: $\mathrm{A}$ gazdaság mozgását a legfejlettebb régiókban már évszázadok óta a tőke uralja. A tőke önmagának gyarapítása a fő cél, mindenkit és mindent a hasznosság alapján ítél meg és értékel. A kultúra ezzel szemben ,az emberiség érdekeit képviselni hivatott a zabolátlan és önkényes piac és állam vonatkozásában" (Buraway, Karikó, 2006.). A gazdaság csak a piacra és kizárólag önmagára tekint. Saját hasznára koncentrál, szemben a kultúrával, amely az egész világra nyitott és az emberiség egyetemes értékeit kívánja szolgálni.

Az idősíkok kereszteződése: A gazdaság piaci szereplöinek érdeke a forgalmazás, a termelés, az üzleti befektetés minél gyorsabb megtérülésének érdekében. Időszemlélete korlátozott, szük, és feltételekkel meghatározott. Fontos, hogy a piaci sikeresség jegyében 
méri az időt. Ezzel szemben a kultúra mozgása lassú, kevésbé mozgalmas. Nem a pillanatnyi siker számít. A kultúra történelmi távlatokban, nemzedékek egymásutániságában mutathatja, mutatja meg önmagát, erejét. A gazdaság az idősíkok szempontjából az áru és a pénzviszonyok vertikális időstruktúrája, a kultúra pedig az egyetemes emberi értékek horizontális időparamétere (Magyari Beck, 2006.). A parciális és az univerzális: A tőke müködése és hatása parciális, egyoldalú, az emberben piaci tényezöt és potenciális fogyasztót lát. A kultúra viszont megjeleníti az adott társadalom egészét és benne az ember univerzitását (Karikó,2006.).

\section{1. äbra: Gazdaság és kultura kapesolata}

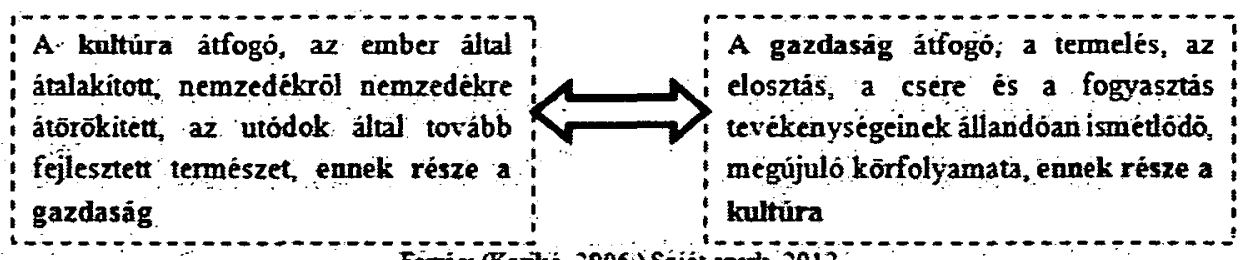

Forras: (Kaniko :2006) Sajat szerk. 2012.

E rövid elméleti áttekintés is bizonyítja, hogy a kultúra és a gazdaság milyen szoros kapcsolatban áll. Egyértelmũ az is, hogy egyik sérülése, avagy fellendülése, a másikat is befolyásolja, erösíti, vagy adott estben gyengíti. A gazdaság állapota a kultúra társadalmi szintü fogyasztásaiból igen jól letérképezhetö.

\section{A FÖLDHASZNÁlAT ÉS A KULTÚRA KAPCSOLATA}

A „,földhasználat"-ot természetesen nem agrárgazdaság szempontjából szeretném a kutatásomban feltüntetni, így elemzése erősen összekapcsolódik a kultúra fogalomkörének kifejtésével. A kultúra itt az abszolút közjavak kategória tagja, fogyasztói pedig az egész társadalom színe java. Magyarország több mint $70 \%$-a mezőgazdasági munkálatokra alkalmas területekböl áll (Szücs,1990.). A gazdaságnak mindig fontos része volt a földművelés. Évszázadokon át kialakult a paraszti élet. Azok a földművelök, akiknek fö tevékenységük a föld megmunkálása és a mezögazdaság. Használják a földet, termelnek, gondoznak, mủvelnek, együtt élnek annak minden rezdülésével. A vizsgálatom tárgya ennek tükrében a kultúra. Latin szóból ered, értelmezése „valamit megmúvelni”. Maga a kultúra szó igazi jelentése is a föld megmúvelésével volt kapcsolatos, hiszen a föld megmúvelési szokásokat, praktikákat és hagyományokat adták át generációról generációra (Márkus, 1992.). Aki nem sajátította el a föld megmüvelésének kultúráját annak megélhetési gondjai lettek. Ma már a kultúra szó másképpen értelmezhető. A kultúra jelentéseinek összessége -

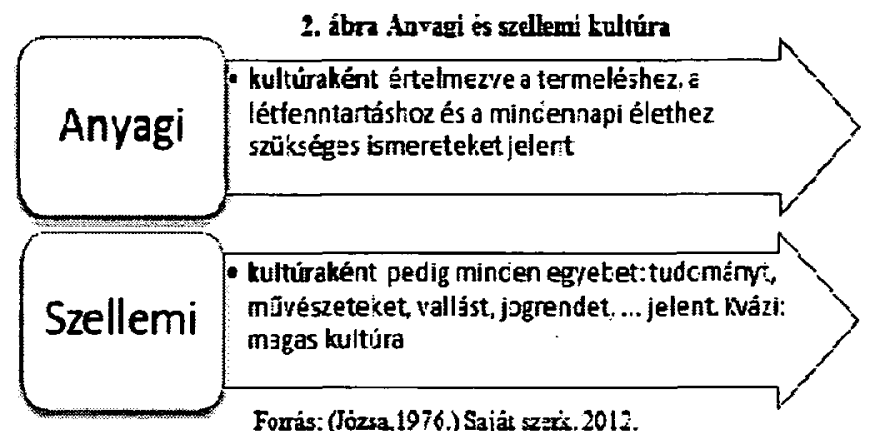

Forrás: (Jỏzsa, 1976.) Sajäi szżs. 2012. legyen az müvészeti értelemben vett, avagy néphagyományokat magyarázó, akár a közösséget összetartó irányelvek egyike - mind egy tőről fakad. A filozófia, a müvelödéstörténet és általában az emberi gondolkodás egyik központi kategóriája lett. Azt feltétlenül elfogadhatjuk, hogy a kultúra soha nem statikus 
jelenség: az emberiség története során állandó változás jellemezte. Az adott társadalom fejlettsége, berendezkedése, objektív valósághoz való viszonya, $s$ mindennek a folyamatos változása feltétlenül befolyásolta az emberiség mindenkori kultúráját (Márkus, 1992.).

A történelemben és az emberi gondolkodásmódban régen két kategóriában élesen különválasztották egymástól az anyagi és szellemi kultúrát.

A mindennapi élet és a gondolkodás fejlödése egyaránt háttérbe szorította a kultúra fentebb vázolt értelmezését. Napjainkban a kultúrát egységesen értelmezzük, hiszen fejlödésük és létezésük egymásra erős hatást gyakorol, azaz kölcsönhatásban vannak egymással. Elég említenünk a tudományos felfedezések termelésre gyakorolt hatását, vagy a technika fejlödésének a szórakozásra, szórakoztatásra gyakorolt hatását, hogy belássuk: a kultúra anyagi és szellemi oldala nem választható el egymástól. „A kultúra mindazon ismeretek, értékek, reflexek, viselkedési modellek és sémák, szokások és hiedelmek összessége, melyeket az egyén az őt felnevelő közegben, a szocializáció során részint megfigyelhető, részint észrevétlen módon elsajátit". (Józsa, 1976.) A vizsgálat kiindulási tárgya lehet az egyén is, aki a társadalom részét képezi. A kultúra, mint a közjavak egyik tényezóje akkor müködhet, ha azt az egyének a születésük után a szocializáció során sajátithatják el. Személyiségük részévé válik, és kulturális attitüdöket eredményez, ami a társadalom egészében realizálódik. A két terület együttes vizsgálata teszi lehetővé a kutatásom során annak meghatározását, hogy mikor és meddig számíthat, a kultúra közjónak illetve mikortól nevezhetem árucikknek, amihez fizetőképes keresletre van szükség. A kereslet szempontjából pedig azt kell értelmezni, mire van szüksége a fogyasztónak, mi az, ami az ő igényeit elégíteni ki, azaz az anyagi kultúrához milyen minőségủ szellemi kultúra társul egyéni szinten.

\section{KöZÖSSÉGBỎL TÖMEG}

$\mathrm{Az}$ eddigi kultúra-kutatások három fó tudományosan magyarázó kategóriát eredményeztek (Józsa, 1967.).

\subsection{TRADICIONÁLIS KULTÚRA:}

Gondoljunk vissza azokra a kis falvakra, településekre, akik csak a földmüvelésböl éltek. A létük a földön megtermelt javaktól függött. Legföbb félelmük az idōjárási viszontagságokban rejlett és babonák, különbözỏ hiedelmek, vallási szokások alapján egy egy évszakfordulón együtt ünnepeltek, jósoltak, hálát adtak a földnek, a földért a jó termés reményében vagy végett. Bátran állíthatjuk, hogy a korai földmúvelés erösen alakította a kulturálódási szokásokat. A földmúvelési szokások vidékenként, falvanként változtak, már csak a természeti adottságok miatt is, igy természetesen a hozzá kapcsolódó népi tradíciók is mind másként alakultak, változtak. /Az alföldön búzatermelés és aratóbál, a dombságokon szőlőmúnvelés és szüreti bálok./ - Mindkét tájegységnek erős és kialakult hiedelemvilága van, rengeteg népi motívummal, amelyek sokat mesélhetnének, mesélnek népünk történetéröl, a természet szeretetéröl. Utalnak a múlt földmüvelési szokásaira mely szokások kulturálódási formákká is kinőtték magukat.

Nemzeti értékeink, szokásaink, hagyományaink kapcsolódnak a mezögazdasághoz és annak müveléséhez. Hagyományainkba „beleszületünk" és a szocializáció során elsajátítjuk. Ezen hagyományok kialakulásában a földmüvelésnek nagy szerepe volt.

\subsection{AUTONÓM KULTÚRA:}

Az ipari forradalom után és az urbanizációnak köszönhetően a tradíciók háttérbe szorultak. Az emberek a városokba tömörültek, többé nem függtek a földtől, hiszen ök nem termeltek élelmiszert, feldolgoztak és szolgáltattak. A mezögazdaság külön vált az ipartól, a városban élő embereknek pedig egyre több lehetőségük adódott arra, hogy 
válogathassanak a különböző kulturálódási formák közül (Madarász, 2010.). Intézményesült a színház, a zene, a táncházak, múzeum, könyvtár és számtalan olyan lehetőség, amit a vidéket mủvelő ember nem kaphatott meg. A város lett tehát a "magas kultúra" melegágya.

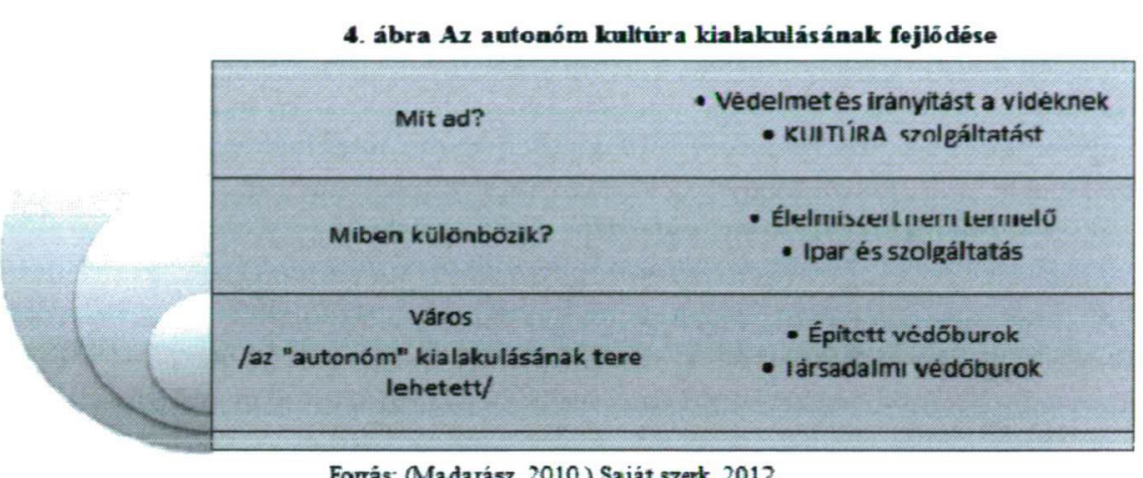

A" magas kultúra" a város szülöttje és erősen globális léptékü, messze kerül a „,föld”-töl és a paraszti kultúrától, holott abból származtatható. Tanulható, igen magas műveltséget ad. Itt már a földmủvelésnek nincs befolyás, de témát adhat és adott is bỏven a paraszti lét, mint ábrázolni kívánt ideák és életek. A mủvészet szinte bármely ágában születtek olyan alkotások melyekben fellelhető az elvágyódás, a vidék és a természet szeretete.

\subsection{HETERONÓM KULTÚRA:}

A városi tömegek mindennapi életét, létfenntartását, szórakozását jelentő kultúrát nevezzük heteronóm kultúrának. A modernizáció és a globalizáció hatására a szabad piacok megjelenésével és az individualista eszmék terjedésével megjelenik a legszéleseb körben elérhető tömegkultúra. A minőségi színvonal nem feltétlen nevezhető magasnak. Gyorsan és könnyen, gondolkodás és elmélyülés nélkül fogyasztható mindenki számára. Elszakadt a „föld"-től, nemzetiségtől.

Három fő kategória segítségével körvonalazható, hogy miként is tipizálható a kultúra fogyasztói társadalom. Kiindulhatunk az egyszerủ földmúvelésből, mely kialakított egy paraszti kultúrát - ami tradíciókat és nemzeti kultúrát hozott létre. Alapvetően ezek az értékek közjavaknak számíthatnak. Fogyasztásukból senki sem zárható ki, mindenki beleszületik és részévé válhat. Megőrzése létfontosságú feladat. A jövőben nagy kihívás, hogy negatív externála ne változtathasson a tradicionális kultúra autentikus jellegén, beleértve itt a globalizáció fogyasztói szokásokat megváltoztató hatását. Különböző korszakokban a tradicionális kultúra "fogyasztói" azonosak voltak a társadalom egészével, később azonban csak a paraszti életet élő rétegek ápolták azt. Ma a tradicionális kultúra a földművelés visszaszorulásának hatására egyre jobban feledésbe merül. Képviselői egyre kevesebben vannak, ami azt a veszélyt is magában hordozza, hogy nem tudja generációról generációra megőrizni és átörökíteni értékeit. A kulturális közjavakból tehát részben,,áru” lesz, igazi piaci szereplöként jelenik meg. A hagyományok és értékek tárgyiasulnak, így fogyasztásuk már megfizethető kereslethez kötődik. A városok fejlődésével megteremtődött a ,magas kultúra" és a fogyasztásának lehetőségei. Itt már a kulturális termékek fogyasztása kézzelfogható termékekhez és szolgáltatásokhoz egyaránt köthető. A termelési folyamat során, amely egyúttal a fogyasztás folyamata is, nem új jószág, hanem értéktöbblet keletkezik. Így a szolgáltatás során a rendelkezésére álló erőforrások úgy kerülnek felhasználásra, hogy a fogyasztó és/vagy a jószág állapotában változások jöjjenek létre, „hozzáadott érték” termelődjön (Demeter - Gelei 2002.). A fogyasztáshoz való hozzáférés azonban nem 
egyformán lehetséges mindenki számára, mivel a kulturális javak megszerzéséhez pénzbeli és időbeni ráfordítások szükségesek. „A magas kultúra nemcsak az európai társadalom müvelt elitjének képzőmüvészetére, muzsikájára, irodalmára és egyéb szimbolikus termékeire vonatkozik, hanem kedvelőik, vagyis a kulturáltak gondolkodási és érzelmi stílusára is. A tömegkultúra viszont a kulturálatlan többség által használt szimbolikus termékeket jelöli"” (Gans,1974.). A trendek és a divatos individualista szellem hatására a magas kultúra mellett megjelenik a tömegkultúra. A fogyasztói körök meghatározásakor tisztázni kell, hogy a tömegkultúra széles körökben könnyen hozzáférhető, elérése elveszti kívánatosságát, tehát rövid ideig tartja fent az érdeklődést. A fogyasztónak nincs ideje az ismeretek feldolgozására. A technikai közlés önállósul. A tapasztalati világ dolgai már nem feltétlen értékesek, a szükséges tudást más magaslatokban vagy mélységekben dimenzionálja. Egyszerü, és bárki számára érthető, olcsó. Passzív befogadásra szoktat. Globális trendek hódítanak, melyek fogyasztásra ösztönöznek. Veszélye abban rejlik, hogy a tradicionális és az autonóm kultúrával versenyez. Amíg a tradicionális és az autonóm a társadalom és az azt fogyasztó részére értéket hoz létre, addig a heteronóm kultúra a társadalmi értékeket és a kultúra minőségi értékét elfecsérli. Fogyasztóit néha el is szigeteli, kizárja az igazi értékek fogyasztásából. A tömegkultúra versenyképessége az „olcsóságában” rejlik. A javak halmozásának trendje ezen olcsó és könnyen, gyorsan fogyasztható „terméket” széles körben népszerüvé teszi. A kutatásomban „közjónak” nevezett tradicionális kultúra mindenki számára elérhető formája veszélybe kerül az ál-individuális és tömegszerü ,termékek" miatt.

\section{Egy új, vitatott dimenzió:}

A kultúradimenziók ismertetésére szerkesztett piramis csúcsán (5. ábra) egy egészen új szellemi és anyagi kulturálódási szemlélet áll, ami nem más, mint a fenntartható fejődés egyéni háztartások szintjén való elsajátítása és ennek következményei. A fenntarthatóság szellemiségü életforma tudatosságot követel meg. Tudatosan kell a mindennapokban létezni és tenni. A fenntarthatóságnak a takarékosság és kíméletesség mellett rengeteg más pozitív tulajdonsága is van. A fenntartható fejlödés üzenete egyénre lefordítva sem merülhet ki a környezetvédelemben és a tudatos vásárlásban, a hulladékhasznosításban és egyéb fontos területekben. Kiterjedése az egyén attitüdjének változásához vezet. A fenntarthatóság életstílus. Életstílus, amely szokásrendszereket reformál, és ami egyértelmủen hatással van az egyén kultúra fogyasztására. Ugyanis a tudatosság sok esetben a minőségi fogyasztásra ösztönöz a szabadidö eltöltése szempontjából. Egyrészt vissza tud térni a régi hagyományokhoz, másrészt elutasító lesz a tömegkultúra irányzataival szemben. Változnak az öltözködési, vásárlási, lakberendezési, technológiai, utazási, kulturálódási, olvasási, zenehallgatási és egyéb számtalan szokásai. A fenntarthatóság és a globalizáció kérdésével foglalkozó elméletek is foglalkoznak a kultúra kérdéskörével és az általuk létrehozott elmélet a „Kulturális reziliencia: Azt a képességet jelenti, hogy egy közösség fenn tudja tartani önazonosságát, és eközben új, praktikus tudásokat vesz alkalmazásba" (Bulla, 2006, UNESCO, 2007)

Az eredmények tükrében talán a legfontosabb felismerés, hogy nemzeti értékeink, szokásaink, hagyományainak kapcsolódnak a mezőazdasághoz, a vidékhez és annak múveléséhez. A tradicionális kultúra fogyasztói is erősen kötődtek vagy kötődnek a mezőgazdasághoz, még ha csak ideák alapján is. Így nem csak az általunk boncolgatott kérdésre kaphatunk választ, hanem arra is magyarázat ez, hogy a tradicionális kulturálódási szokások nemzetenként miért különbözhetnek. A különböző éghajlatokon, más időjárási viszontagságok között más természeti adottságok mellett, más életritmusban, különböző növényeket és állatokat tartanak, amelyek más nemzeti szokásokat okoztak, okoznak. A városiasodás miatt kialakuló autonóm kultúra már nem csak nemzeti, hanem sokkal homogénebb. Annak fogyasztása nem kötődik tradíciókhoz. Nemzetközi és bárhol 
megkapható fogyasztási cikk, amelyhez szabadidő feláldozásával és némi anyagi kiadással tudunk csak hozzájutni. Fogyasztói rétegei ezért jól körvonalazhatóak. A modernizáció ideje alatt a kultúra, mint fogalom további jelentésekkel bővült. A modernizáció és a globalizáció hatására a szabad piacok megjelenésével és az individualista eszmék terjedésével megjelenik a legszéleseb körben elérhető tömegkultúra.

\section{A MARKETING FELADATA}

Miért van szükség kultúra marketingre? A fent említett kultúra dimenziók

\section{5. ábra A kultúra allomásai}

\section{Fenntartható fejlōdés és a tudatos életmód megjelenése új} kulturafogyasztói réteg kialakulása.

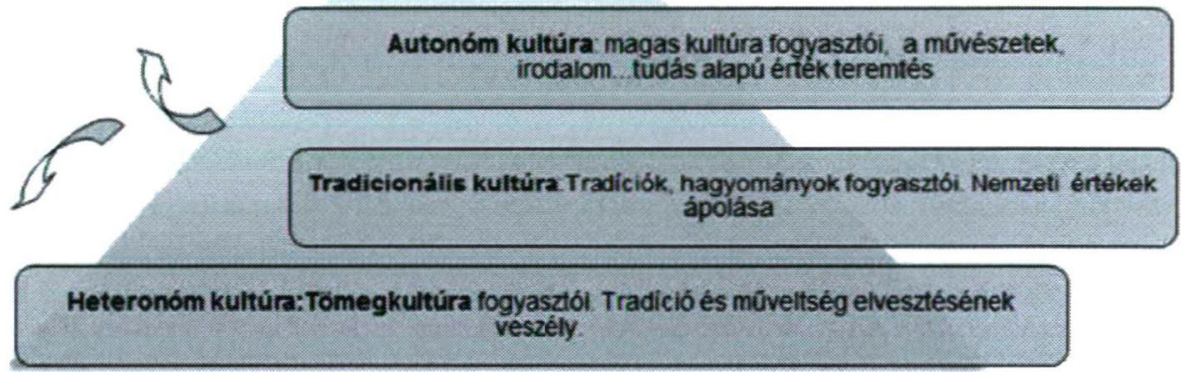

Forràs: (Józsa, 1976. Wessely, 2003.Császi, 2011.) Sajảt szerk. 2012.

népszerűségének segítésére alkalmazhatjuk a marketing eszközeit és elméletei. Fontos, hogy az egyes dimenziók marketinges fogásai alkalmazható modellként szolgáljanak más dimenziók számára is. A tömegkultúrát népszerüsítő úgynevezett „kultúra technológiákat” adaptálni lehet a tradicionális és az autonóm kultúra javára. Például a valóságshow-kat alkalmazni nemesebb célokra. (Császi, 2011.) A marketing elsődleges feladata a választott témán belül a jelenlegi társadalom kultúra fogyasztói csoportjainak helyes meghatározása. Annak tudatos vizsgálata, hogy a fogyasztók igényei nincsenek kielégítve, miért nincsenek? - és pontosan mi azok az igények? A marketing eszközök széles tárháza biztosítja a technikai hátteret ahhoz, hogy a tömegkultúra által kitaposott ösvényeken keresztül értéket teremthessünk. A tömegkultúra népszerüsítésére használt eszközöket a minőségi kultúra oldalán is alkalmazni kell. A fogyasztókat tájékoztatni és nevelni kell. Kihívást jelenthet még annak a kérdésnek a megválaszolása is, hogy a kultúra fogyasztói szegmensei között milyen átjárhatósági arányok vannak, hiszen a tradicionális kultúra része lehet az autonóm és fordítva. Sajátos piackutatás során a legfontosabb kérdés az egyes dimenziók iránti kereslet és a dimenziókban elérhető „termék” minőségi szintjeinek meghatározása. A következő lépés az átjárhatóság értelmezése a dimenziók között - azért szükséges, hogy az arra alkalmas müfajokat összekapcsoljuk és marketing eszközökkel a jövőben hatékonyan népszerüsíthessük. A kutatás közben pedig meghatározódik a kizárólagosság igénye vagy lehetősége is, hiszen lesznek olyan fogyasztók, akik nem tartanak igényt a minőségi kultúrafogyasztás lehetőségére. Ezen kategóriákat a jövőben fogyasztói magatartás vizsgálattal kívánom bizonyítani. Marketing feladatai közzé tartozik még a kínálati oldal meghatározása is. A fenti három dimenzió abban is különbözik egymástól, hogy a kínálatban egyaránt szerepelnek „közjavak” és „áruk”. Ezen témakörök meghatározása szintén marketinges célkitủzésem a jövőben. 
Példa egy marketinges eszköz használatára: A népszerü és tömegeket megmozgató flashmob - (Magyar jelentése villámcsödület. A fogalom jelentése emberek elöre szervezett csoportosulását jelenti, amely hirtelen jön létre valamilyen nyilvános helyen, a résztvevők valami szokatlant csinálnak, majd a csoportosulás ugyanolyan hirtelen fel is oszlik, ahogy létrejött. A jelenség célja a figyelemfelkeltés, a hétköznapi ember elgondolkodtatása.) - mint eszköz, ma már nem csak tömeg - kulturális fogyasztókat tud megmozgatni és megnyerni, hanem ezen eszközt alkalmazva eljuttathatjuk hozzájuk a minőségi és értékteremtő és hordozó kultur"termékeket" is. A Budapesti Tavaszi Fesztivál szervezésében 2012. március 23.-án Budapest különböző pontjain szervezett flashmob - ok különleges hangulatban teltek. Népszerüek voltak Kodály kórusművei, a Bánk bán bordala, a palotás vagy a Háry János és a Székely fonó részletei egyaránt. Ez az esemény „Énekel a város” névre hallgatott.

\section{KÖVETKEZTETÉSEK, JAVASLATOK, ÖSSZEFOGLALẢS:}

A fent leirtak igazolják a téma érvényességét és rámutatnak egy késöbbi feltáró kutatás szükségességére. A szakirodalomban feltárt eredmények pedig arra ösztönöznek, hogy a témakör további vizsgálata hiánypótló jellegủ. Fö kutatási célkitüzéseim egyik fontos pontja, a tradicionális és az autonóm kultúrafogyasztást közgazdasági értelemben való megfogalmazása és prezentálása, a közjó, az árucikk és az externáliák pontos definícióinak kialakítása. Vizsgálatom tárgya továbbá a heteronóm kultúra marketing tevékenységének elemzése és esetleges adaptálása. Későbbiekben ezek vizsgálatára kvalitatív és kvantitatív kutatásokat is tervezek.

\section{FELHASZNÁLT IRODALOM}

Karikó Sándor (2006): Gazdaság és /vagy kultúra, Gondolat Kiadó, Budapest.

Kovalcsik József (2003): A kultúra csarnokai, Seridan Kft. Budapest.

Gans, Herbert (2003): Népszerü kultúra és magas kultúra In: Wessely Anna (2003): A kultúra szociológiája, Osiris, Budapest.

Józsa Péter (1976): Kód - kultúra -kommunikáció, NPI, Budapest.

Madarász Imre (2010.): Városszociológia, Egyetemi jegyzet, Szent István Egyetem Könyvkiadó, Gödöllö

Magyari Beck István (2006): Kulturális marketing és kreatológia, Semmelweis kiadó, Budapest.

Márkus György (1992): A kultúra: egy fogalom keletkezése és tartalma, T-Twins Kiadó és MTA Könyvtár Lukács Archívum, Budapest.

Neulinger Ágnes - Vígvári Dorottya: A kultúrafogyasztás aktuális kérdései, http://www.fvszemle.hu/archivum/2011_marcius/muhely/kulturafogyasztas/2012. április 11 . $20: 10$

Szücs István (1990): Verseny és rendszerszemlélet a földhasznositásban, Közgazdasági és jogi kiadó, Budapest.

Tamás Pál - Bulla Miklós (2011): Sebezhetőség és adaptáció; A reziliencia esélyei, in: Császi Lajos, Sebezhetőség és kockázat a szórakoztató médiában, 415.-429. o. MTA Szociológiai Kutatóintézet, Budapest.

Tátrai Zsuzsanna - Karácsony Molnár Erika (1997): Jeles napok, ünnepi szokások, Mezỏgazda kiadó, Budapest.

Tomka Béla (2009): Európa társadalom ismerete a 20. században; Osiris, Budapest.

Wessely Anna (2003): A kultúra szociológiája, Osiris, Budapest. 